\title{
URGENSI DAN PENGATURAN UU TENTANG CONTEMPT OF COURT UNTUK MENJAMIN HARKAT, MARTABAT DAN WIBAWA PERADILAN
}

\author{
Oleh: \\ Aditya Wisnu Mulyadi ${ }^{1}$
}

\begin{abstract}
The phenomenon of the Contempt of Court is an event that is rife in Indonesia lately. It is considered to reduce the dignity, majesty and authority of the judiciary and its apparatus. Particularly the dignity and authority of the judge. Attitudes and actions displayed by the search for justice, legal practitioners, the press, political and social organizations, NGOs, academics, judicial commission, as well as various other parties in such a way can be categorized injure the dignity, majesty and authority of the judiciary, good attitude and actions directed against the judicial process, judicial officials, as well as court decisions. Lack of strict legal instruments and adequate to serve as guidelines and benchmarks to judge such a phenomenon is made Contempt of Court always the case. View of the judge is an arm of God would have been contrary to Contempt of Court. The judge in charge of prosecuting and providing justice for justice seekers should not accept the bad treatments. This study is based on normative research method using statutory approach and conceptual approaches. Legislation that used is Law No. 4 of 1985 on the Supreme Court, Code of criminal law, the law book of the law of criminal procedure, the draft book of the Criminal Justice Act 2012 and draft the Code of Criminal Procedure 2012. This research is expected to contribute significantly for the creation benchmarks and appropriate guidelines in terms of the establishment of regulations and legislation on Contempt of Court Act.
\end{abstract}

\section{Keywords: Contempt of Court, Dignity, Authority, Justice}

\section{PENDAHULUAN}

\subsection{Latar Belakang}

Persoalan akhir-akhir ini mengenai Contempt of Court di Indonesia merupakan suatu permasalahan yang menarik sekaligus pelik dalam suatu konsepsi dan regulasinya. Terminologi dan pengertian dari Contempt of Court di indonesia pertama kali terdapat dalam UU Mahkamah Agung yang konklusi utama pengertiannya adalah tindak pidana

Mahasiswa Program Magister (S2) Ilmu Hukum Universitas Udayana, Denpasar, Bali, Alamat: Jalan Batanghari XI No: $6 \mathrm{Kec}$. Panjer Kab. Denpasar, Email: adityawisnu1991@yahoo.co.id yang melibatkan seseorang atau lebih dalam perkara di sidang pengadilan ataupun tidak baik yang berada di luar ataupun dalam pengadilan yang perbuatannya secara aktif maupun pasif mengganggu dan mengotori sistem peradilan pidana yang berjalan sebagaimana mestinya, menghalangi dan mengganggu para pejabat pengadilan yang berwenang dalam menjalankan tugasnya, merendahkan harkat, martabat dan wibawa keagungan peradilan di depan khalayak umum karena diibaratkan sidang pengadilan merupakan suatu yang sakral dan hakim merupakan perpanjangan tangan Tuhan karena melalui hakimlah diharapkan 
didapatkannya suatu keadilanyang mencakup seluruh pihak yang bersengkata.

Indonesia, sebagai sebuah Negara berdasarkan atas hukum (rechtstaat) diartikan dalam penyelenggaraan kekuasaan negara harus diatur, sesuai dan dijalankan berdasarkan atas hukum. Dalam konteks ini, selain kekuasaan eksekutif dan legislatif, terdapat kekuasaan yudikatif dalam manifestasi berbentuk kekuasaan kehakiman.

Pada kekuasaan kehakiman terdapat asas fundamental berupa independence of judiciary. Asas tersebut mengandung makna bahwa jalannya proses peradilan harus dijamin sedemikian rupa agar terhindar dari segala bentuk pengaruh, tekanan, ancaman yang datang dari pihak manapun juga yang berpotensi dapat mereduksi keluhuran asas tersebut. Asas independence of judiciary merupakan asas bersifat universal dan diberlakukan di pelbagai Negara.

Dari konteks asas tersebut di atas, proses peradilan harus dijalankan secara terbuka, obyektif, imparsial sesuai dengan ketentuan hukum dan rasa keadilan. Sedemikian pentingnya kedudukan dan fungsi asas tersebut sehingga mendapatkan pengaturan secara khusus dalam UUD $\mathrm{N}$ RI Tahun 1945 serta kemudian dijabarkan ke dalam pelbagai UU yang secara khusus berisi tentang pokok-pokok kekuasaan kehakiman. Siapapun juga, tanpa terkecuali, berkewajiban untuk menghormati martabat, keluhuran dan wibawa lembaga pengadilan maupun segenap aparaturnya.

Namun demikian, dalam dinamika perkembangan akhir-akhir ini terdapat fenomena menarik yang dapat mereduksi martabat, keluhuran dan wibawa lembaga peradilan beserta aparaturnya. Terutama harkat dan wibawa hakim. Sikap dan tindakan yang ditampilkan oleh pencari keadilan, praktisi hukum, kalangan pers, organisasi sosial politik, lembaga swadaya masyarakat, akademisi, komisi yudisial, serta berbagai pihak lainnya yang sedemikian rupa dapat dikategorisasikan mencederai martabat, keluhuran dan wibawa peradilan, baik sikap dan tindakan yang ditujukan terhadap proses peradilan, pejabat peradilan, maupun putusan pengadilan.

Selain itu, pada pelaksanaan kekuasaan kehakiman dalam praktek ketatanegaraan relatif rentan dapat diintervensi, baik melalui kebijakan hukum pembuat undangundang, lembaga horizontal, kekuatan di dalam masyarakat (organisasi massa, media massa, partai politik) melalui pembentukan pendapat umum (public opinion) pada saat peradilan sedang berlangsung. Pengaruh pihak-pihak yang mempunyai kepentingan politik kekuasaan, kekerasan atau pengerahan massa yang bersifat anarkhis, tegas dan memaksa mewarnai proses peradilan sehingga mengganggu penyelenggaraan proses peradilan.

Pada hakekatnya, urgensi dan latar belakang tentang undang-undang contempt of court penting eksistensinya. Sebagai contoh untuk perumpamaan dapat dilihat di sebuah gedung pengadilan, dimana pada kasus-kasus yang dapat menarik minat masyarakat untuk menontonnya tidak jarang gedung pengadilan penuh sesak dipadati oleh masyarakat-masyarakat yang ingin untuk menyaksikan jalannya persidangan dan tidak jarang pula beberapa dari mereka 
melakukan perbuatan-perbuatan yang tidak sesuai dengan etika dan keagungan dari peradilan itu sendiri. Misalkan saja apabila hasil putusan hakim dianggap tidak sesuai dengan cita hukum dan keadilan masyarakat, mereka mengumpat dan melakukan halhal yang melanggar kenyamanan para pejabat pengadilan Selain itu, kadang ada massa berdemonstrasi menuntut dihentikan proses persidangan, dituntut hukum mati, dibebaskan terdakwa, dan lain sebagainya.

Kemudian juga terjadi kasus dimana penasehat hukum yang tidak puas dan senang dengan putusan hakim melayangkan keberatan dan menginterupsi dengan seenaknya tanpa mengindahkan etika sebuah sistem peradilan pidana yang sebenarnya. Dalam kasus yang lebih ekstrim lagi bahkan kita dapat melihat terdakwa sendiri yang menyerang seorang hakim yang sepatutunya diagungkan dan dimuliakan.

Bila berbicara mengenai luar persidangan, pemberitaan media yang tiada hentinya mengenai kritik ataupun saran turut memberikan pengaruh signifikan terhadap putusan yang akan dijatuhkan oleh hakim, tidak jarang media membesar-besarkan pemberitaan tersebut dan memunculkan suatu anggapan bahwasanya seseorang yang telah berada di depan pengadilan yang menjalani sidang pidana maupun perdata telah diputus terbukti bersalah secara sah dan meyakinkan walaupun proses peradilan tersebut belum selesai, tentu saja kondisi ini berpengaruh terhadap citra orang tersebut di masyarakat.

Dari latar belakang masalah yang telah dipaparkan penulis tersebut diatas menarik untuk membuat karya ilmiah dengan judul "Urgensi dan Pengaturan UU Tentang Contempt of Court Untuk Menjamin Harkat, Martabat dan Wibawa Peradilan".

\subsection{Rumusan Masalah}

Bertitik tolak pada persoalan maupun fenomena yang telah penulis deskripsikan tersebut diatas dapat ditarik 2 masalah pokok, antara lain:

1) Bagaimana pengaturan Contempt of Court di hukum positif Indonesia (Ius Constitutum/Ius Operatum) dan hukum yang akan datang (Ius Constituendum).

2) Bagaimana formulasi ruang lingkup karakteristik perbuatan yang dapat dikategorikan sebagai Contempt of Court pada masa mendatang (Ius Constituendum).

\subsection{Tujuan Penelitian}

Penelitian hukum ini mempunyai 2 tujuan yakni Tujuan Umum dan Tujuan Khusus:

1) Tujuan Umum: Untuk mengetahui pengaturan mengenai Contempt of Court dalam hukum yang berlaku di Indonesia sekarang ini dan hukum yang akan dating.

2) Tujuan Khusus: Tujuan khusus dari penelitian hukum ini adalah memaparkan dan mengkaji secara terperinci mengenai ruang lingkup karakteristik perbuatan-perbuatan yang dapat di kategorikan sebagai Contempt of Court pada amsa mendatang (Ius Constituendum) 


\section{Metode Penelitian}

\subsection{Jenis penelitian}

Menurut William H. Putman, "Legal research is a part of the legal analysis process. It is that part of the legal analysis process that involves finding the law that applies to the legal question raised by the facts of client's case". ${ }^{2}$ (Terjemahan bebas: Penelitian hukum adalah bagian dari proses analisis hukum termasuk mencakup dalam hal menemukan hukum yang dapat diaplikasikan dalam pertanyaan hukum yang diajukan berdasarkan fakta-fakta dari kasuskasus).

Penelitian ini bertumpu pada penelitian hukum normatif atau dogmatik (dogmatic law research) ${ }^{3}$ karena hakikat mendasar penulisan ini ialah untuk menemukan dan mengkaji mengenai peraturan UU mengenai Contempt of Court dalam rangka menjamin terwujudnya kepastian hukum berhubungan dengan harkat, martabat dan wibawa hakim di dalam peradilan.

\subsection{Jenis Pendekatan}

Dinamika penelitian hukum terdapat berbagai macam pendekatan antara lain pendekatan perundang-undangan (statute approach), pendekatan kasus (case approach), pendekatan historis (historical approach), pendekatan komparatif (comparative approach), dan pendekatan konseptual (conceptual approach). ${ }^{4}$
Penelitianinibertumpupadapendekatan perundang-undangan yaitu mengkaji UU yang relevan dengan permasalahan yang dibahas yaitu Contempt of Court dan juga Pendekatan konseptual yang meneliti bagaimana terminologi daripada Contempt of Court tersebut.

\subsection{Sumber Bahan Hukum}

Bahan hukum yang akan dikaji dan dianalisis dalam penelitian ini terdiri dari bahan hukum primer, sekunder dan tersier. ${ }^{5}$

Bahan hukum primer adalah yang memiliki kekuatan mengikat, ${ }^{6}$ berupa peraturan perundang-undangan yang terkait dengan Urgensi dan Pengaturan UU Tentang Contempt of Court Untuk Menjamin Harkat, Martabat dan Wibawa Peradilan, yaitu UU No. 4 Tahun 1985 Tentang Mahkamah Agung.

Bahan hukum sekunder berupa bahanbahan hukum yang akan memberikan suatu kejelasan dan pemahaman terhadap bahan hukum primer seperti literatur (baik asing maupun tidak), hasil-hasil penelitian, putusan pengadilan, makalah dalam seminar serta artikel-artikel yang memiliki hubungan dengan masalah yang dibahas.

Sedangkan bahan hukum tersier ialah bahan hukum yang dapat memberikan arahan dan kejelasan terhadap bahan hukum primer maupun sekunder yaitu berupa kamus (dictionary) atau ensiklopedi.
William H. Putman, 2009, Legal Research: Second Edition, Delmar, United States of America, hlm.372 Peter Mahmud Marzuki, 2009, Penelitian Hukum, Kencana Prenada Media Group, Jakarta, hlm.35.

4 Soerjono Soekanto \& Sri Mamudji, 2006, Penelitian Hukum Normatif, PT. Raja Grafindo Persada, Jakarta, hlm.37.
Sutrisno Hadi, 2010, Methodologi Research I, Gadjah Mada University, Semarang, hlm.26

H. Salim \& Erlies Septiana Nurnani, 2013, Penerapan Teori Hukum Pada Penelitian Tesis dan Disertasi, PT. Raja Grafindo Persada, Jakarta, hlm.16. 


\subsection{Teknik Pengumpulan Hukum}

Metode pengumpulan bahan hukum diperoleh dengan cara mengumpulkan UU, konvensi-konvensi internasional, literaturliteratur, jurnal hukum, ${ }^{7}$ dan lain sebagainya yang berhubungan dengan persoalan Urgensi dan Pengaturan UU Tentang Contempt of Court Untuk Menjamin Harkat, Martabat dan Wibawa Peradilan kemudian dilanjutkan dengan penyortiran bahan-bahan tersebut yang terkait dengan permasalahan yang dibahas.

\subsection{Teknik Pengolahan dan Analisis Bahan Hukum}

Teknik pengolahan bahan hukum dalam penelitian ini menggunakan teknik deskripsi, argumentasi, interpretasi dan sistematisasi. Teknik deskripsi penulis gunakan terhadap "isi maupun struktur hukum yang berlaku sekarang ini” yang berhubungan dean memiliki korelasi erat dengan pokok permasalahan yang dipaparkan oleh penulis.

Bahanhukumyang telahdideskripsikan secara terperinci selanjutnya disesuaikan makna dan pengertiannya melalui metode interpretasi. $^{8}$ Bahan hukum yang telah dideskripsikan dan diinterpretasikan sesuai pokok permasalahan selanjutnya di sistematisasi, dieksplanasi dan diberikan argumentasi.

Johny Ibrahim, 2005, Teori dan Metodologi Penelitian Hukum Normatif, Bayu Media, Malang, hlm.284.

8 Yudha Bhakti Ardhiwisastra, 2000, Penafsiran dan Konstruksi Hukum, Alumni, Bandung, hlm.20.

\subsection{Pengaturan Contempt of Court} dalam Hukum Positif Indonesia (Ius Constitutum/Ius Operatum) dan hukum yang akan datang (Ius Constituendum)

Di Indonesia, pengaturan Contempt of Court dalam hukum positif(Ius Constitutum) Ius Operatum) selintas diatur dalamketentuan hukum materiil (KUHP), hukum formal (KUHAP), maupun pengaturan di luar KUHP dan KUHAP, untuk Ius Constituendum dalam RUU KUHAP Tahun 2012 dan RUU KUHP Tahun 2012. Ketentuan hukum materiil dan hukum formal yang mengatur Contempt of Court dalam kebijakan formulasi tersebut, relatif tidak dapat dilaksanakan untuk "menjerat" pelaku tindak pidana Contempt of Court pada tahap aplikatifnya.

Dalam KUHP dan KUHAP diatur selintas mengenai Contempt of Court yang intinya adalah siapapun yang dengan sengaja mengganggu, tidak menunjukkan rasa hormat dan menghalang-halangi kinerja pejabat yang berwenang baik di dalam sidang maupun luar persidangan di hukum dengan hukuman pidana dengan tenggat waktu tertentu.

Sedangkan inti Pasal yang mengatur tentang Contempt of Court dalam RUU KUHP dan KUHAP 2012 yakni hakim ketua dalam persidangan wajib dihormati, oleh sebab itu bagi siapa saja yang berada di dalam suatu persidangan tersebut yang malakukan perbuatan yang melanggar etika peradilan, berbuat yang dianggap merendahkan harkat, martabat dan wibawa seorang hakim yang merupakan perpanjangan tangan Tuhan 
dan yang memberikan keadilan diberikan peringatan oleh ketua hakim sidang, apabila peringatan tersebut tidak diindahkan dan di anggap angin lalu saja atas perintah ketuan hakim sidang yang bersangkutan dapat dikeluarkan dari dalam suatu persidangan.

Tegasnya, dengan lain perkataan, dapat dikatakan bahwa kenyataannya hingga saat ini, Indonesia masih belum memiliki perangkat hukum tersendiri yang memadai untuk mengatur dan melindungi martabat, keluruhan dan wibawa peradilan dari berbagai tindakan berbagai pihak. Indikasinya, relatif sedikit yang diadili karena melakukan Contempt of Court. Konsekuensi logisnya, merupakan kebutuhan bersifat urgen, segera dan mendesak untuk dilakukan kajian dan penelitian secara kritis, akademis dan bersifat komprehensif terhadap lahirnya eksistensi UU tentang Tindak Pidana Penyelenggaraan Peradilan dalam rangka menjaga keluhuran dan menegakkan martabat dan wibawa peradilan.

\subsection{Formulasi Ruang Lingkup Karakteristik Perbuatan Yang Dapat Dikategorisasikan Tindak Pidana Contempt of Court pada Masa Mendatang}

Konsekuensi logis dimensi konteks di atas, dirasakan kebutuhan relatif perlu dan mendesak negara Indonesia harus sesegera mungkin mempunyai dan mewujudkan adanya UU tentang Tindak Pidana Penyelenggara Peradilan (Contempt of Court) dalam kerangka negara hukum dan mewujudkan kekuasaan kehakiman yang bertumpu pada keadilan independent guna mencapai penyelenggaraan peradilan yang diharapkan dapat menjamin hukum dan keadilan berpedoman pada dasar negara RI yaitu Pancasila dan UUD N RI Tahun 1945.

Untuk itu, guna mencapai fungsi kekuasaan kehakiman untuk menegakkan hukum dan keadilan yang merdeka, pada konferensi Ketua Mahkamah Agung seAsia Pasifik mensyaratkan perlu adanya pengaturan Contempt of Court diantaranya "Safe Guard of Judiciary". Kemudian Beijing Statement memberikan salah satu standart minimum menjaga independensi dan efektivitas fungsi peradilan melalui asas Independence of the Judiciary.

Dalam rangka konteks demikian, Oemar Seno Adji menyebutkan bahwa kekuasaan kehakiman mengandung aspek kebebasandalammenjalankantugasperadilan (within the exercise of the judicial function), sehingga sebagai kebebasan "personlijk/ rechtspositio" mengandung di dalamnya "vervod" yaitu larangan bagi kekuasaan negara lainnya untuk melakukan intervensi dan "gebod" sebagai kewajiban bagi hakim dalam menjalankan tugasnya dibimbing oleh hati nurani yuridisnya. ${ }^{9}$

Refleksi konteks kekuasaan kehakiman yangmerdekadisampingmengandungmakna eksistensi independence of judiciary juga terdapat dimensi Hak Asasi Manusia (HAM). Aspek dan dimensi ini mutatis mutandis terdapat dalam Universal Declaration of Human Rights, yang kemudian tercermin di ICCPR. ${ }^{10}$

Oemar Seno Adji, 2007, Peradilan Bebas Negara Hukum, Erlangga, Jakarta, hlm.252.

10 Manuarar Siahaan, 2013, Pendapat Ahli IV, Majalah Varia Peradilan Nomor: 327, Ikatan Hakim Indonesia (IKAHI), Jakarta, hlm.45. 
Pada dasarnya, pembagian Contempt

of Court dikhususkan menjadi civil Contempt of Court dan criminal Contempt of Court. Adapun civil Contempt of Court adalah penolakan ataupun sangkalan terhadap perintah maupun putusan dari pengadilan, jadi bersifat perlawanan terhadap pelaksanaan hukum (an offence against the enforcement of justice), dimana sanksinya bersifat paksaan (coercivenature). Kemudian criminal Contempt of Court merupakan segala bentuk perlakuan-perlakuan yang mengganggu atau menjadi batu sandungan dalam proses penyelenggaraan peradilan (an offence against the administration of justice) dimana sanksinya berupa pidana (punitif nature).

Selain itu, dikaji dari perspektif jenisnya, Oemar Seno Adji menyebutkan beberapa jenis Contempt of Court, yaitu: Sub judice rule, yaitu perbuatan penghinaan dengan cara pemberitahuan atau publikasi; Disobeying Court Orders, yaitu tidak mentaati perintah-perintah pengadilan misalnya saja tidak menghormati hakim ketua sebagai ketua dalam sidang Pengadilan; Obstructing Justice, yaitu menghalanghalangi jalannya penyelenggaraan peradilan yang tentunya dapat menimbulkan suasana yang tidak harmonis dalam suatu sidang Pengadilan; Misbehaving in Court, yaitu berprilaku tercela dan tidak pantas di pengadilan misalnya berkata-kata kasar pada hakim di Pengadilan ataupun meludah; dan Scandalising the Court, yaitu menyerang integritas dan impartialitas pengadilan. ${ }^{11}$

11 Ibid, hlm.256.
Kemudian Barda Nawawi Arief mengklasifikan jenis Contempt of Court, yaitu: berupa gangguan yang dilakukan oleh seseorang di dalam sidang pengadilan baik disengaja maupun tidak yang telah mengganggu ketentraman jalannya ruang sidang tersebut; Perlakuan-perlakuan yang dilakukan oleh seseorang dalam rangka mempengaruhi para pejabat yang berwenang untuk mewujudkan proses peradilan yang tidak berat sebelah sehingga terciptanya peradilan yang adil; Perbuatan yang menimbulkan rasa malu dan dapat memunculkan suatu citra yang tak bagi pengadilan, misalnya saja mafia peradilan; Perbuatan yang mengganggu kenyamanan para pejabat pengadilan, karena pejabat peradilan merupakan pejabat yang berwenang yang ditangan merekalah diharapkan keadilan dapat terwujud oleh sebab itu tidak sepatutnya diperlakukan dengan kasar; Perbalasan berkaitan dengan sikap-sikap yang dilakukan pada saat proses peradilan masih berlangsung, tentu saja perbuatan seperti ini pula dianggap sangat merendahkan harkat dan martabar peradilan di depan masyarakat umum; Perbuatan pelanggaran yang dilakukan oleh para pejabat pengadilan yang berwenang berkaitan dengan kewajiban-kewajiban yang diembannya dan Perbuatan yang dikategorikan sebagai pelanggaran oleh penasehat hukum misalkan saja menginterupsi putusan ketua hakim pada saat proses sidang peradilan masih berlangsung. ${ }^{12}$ Perbuatan-perbuatan seperti

12 Barda Nawawi Arief, 2008, Bunga Rampai kebijakan Hukum Pidana, Perkembangan Penyusunan Konsep KUHP Baru, Kencana Prenada Media Group, Jakarta, hlm.72. 
dijelaskan tersebut diatas sangat mengurangi bahkan tidakjarang dianggap menghilangkan harkat dan martabat seorang hakim di dalam suatu peradilan dan di depan masyaratakat awam.

Pada hakekatnya, formulasi ruang lingkup karakteristik perbuatan yang dapat dikategorisasikan tindak pidana Contempt of Court masa mendatang (ius constituendum) melingkupi apa yang telah diuraikan konteks di atas.

\section{PENUTUP}

\subsection{Simpulan}

Bertitik tolak pada pemaparan tersebut diatas dapat diambil simpulan bahwasanya pengaturan Contempt of Court dalam hukum positif Indonesia (Ius Constitutum) masih terdapat di pelbagai UU yang berlaku saat ini sebut saja, KUHP dan KUHAP. Sementara untukIus Constituendum terdapat dalam RUU KUHP dan RUU KUHAP 2012. Sedangkan formulasi ruang lingkup karakteristik perbuatan yang dapat dikategorisasikan tindak pidana Contempt of Court masa mendatang (ius constituendum) adalah gangguan yang dilakukan oleh seseorang di dalam sidang pengadilan baik disengaja maupun tidak yang telah mengganggu ketentraman jalannya ruang sidang tersebut; Perlakuan-perlakuan yang dilakukan oleh seseorang dalam rangka mempengaruhi para pejabat yang berwenang untuk mewujudkan proses peradilan yang tidak berat sebelah sehingga terciptanya peradilan yang adil; Perbuatan yang menimbulkan rasa malu dan dapat memunculkan suatu citra yang tak bagi pengadilan, misalnya saja mafia peradilan;
Melakukan tindakan yang mengganggu para pejabat pengadilan; Perbalasan berkaitan dengan sikap-sikap yang dilakukan pada saat proses peradilan masih berlangsung, tentu saja perbuatan seperti ini pula dianggap sangat merendahkan harkat dan martabar peradilan di depan masyarakat umum; Pelanggaran yang dilakukan oleh para pejabat pengadilan yang berwenang berkaitan dengan kewajiban-kewajiban yang diembannya dan Perbuatan yang dikategorikan sebagai pelanggaran oleh penasehat hukum misalkan saja menginterupsi putusan ketua hakim pada saat proses sidang peradilan masih berlangsung.

\subsection{Saran}

Pengaturan mengenai Contempt of Court dalam Sistem Peradilan Pidana Indonesia kurang memadai karena masih tersebar dibeberapa peraturan perundangundangan oleh karena itu diperlukannya aturan tersendiri untuk mengatur tindak pidana Contempt of Court dengan mewujudkan terbentuknya UU mengenai tindak pidana penyelenggara pengadilan (Contempt of Court). Agar kedepannya di dapatkannya prospek pengaturan hukum yang lebih menjamin kewibawaan dan martabat seorang hakim pada khususnya dan peradilan pada umumnya.

\section{DAFTAR BACAAN}

\section{Buku}

Adji, Oemar Seno, 2007, Peradilan Bebas Negara Hukum, Erlangga, Jakarta

Ardhiwisastra, Yudha Bhakti, 2000, 
Penafsiran dan Konstruksi Hukum, Alumni, Bandung.

Arief, Barda Nawawi, 2008, Bunga Rampai kebijakan Hukum Pidana, Perkembangan Penyusunan Konsep KUHP Baru, Kencana Prenada Media Group, Jakarta.

Hadi, Sutrisno, 2010, Methodologi Research I, Gadjah Mada University, Semarang.

Ibrahim, Johny, 2005, Teori dan Metodologi Penelitian Hukum Normatif, Bayu Media, Malang.

Marzuki, Peter Mahmud, 2009, Penelitian Hukum, Kencana Prenada Media Group, Jakarta.

Putman, William H., 2009, Legal Research: Second Edition, Delmar, United States of America.

Salim, H., \& Nurnani, Erlies Septiana, 2013, Penerapan Teori Hukum Pada Penelitian Tesis dan Disertasi, PT. Raja Grafindo Persada, Jakarta.

Soekanto, Soerjono \& Mamudji, Sri, 2006, Penelitian Hukum Normatif, PT. Raja Grafindo Persada, Jakarta.

Siahaan, Manuarar, 2013, Pendapat Ahli IV, Majalah Varia Peradilan Nomor: 327, Ikatan Hakim Indonesia (IKAHI), Jakarta

\section{Perundang-undangan}

Kitab UU Hukum Acara Pidana (KUHAP)

Kitab UU Hukum Pidana (KUHP)

Rancangan Kitab UU Hukum Pidana Tahun 2012 (RKUHP 2012)

Rancangan Kitab UU Hukum Acara Pidana 2012 (RKUHAP 2012).
UU No. 4 Tahun 1985 Tentang Mahkamah Agung

\section{Biodata Penulis:}

Aditya Wisnu Mulyadi, SH

Jalan Batanghari XI No: 6 Denpasar 089651300611

adityawisnu1991@yahoo.co.id 